\title{
Colonization of Nishino-shima Island by Plants and Arthropods 31 Years after Eruption ${ }^{1}$
}

\author{
Tetsuto Abe $e^{2}$
}

\begin{abstract}
Although many researchers have studied colonization, the process has rarely been observed on newly emerged oceanic islands. To describe the colonization process of a remote oceanic island, I investigated the flora, vegetation, and pollinators of Nishino-shima Island $31 \mathrm{yr}$ after a major eruption in 1973. Nishino-shima Island, which is 22 ha in size, is located 1,000 km south of mainland Japan. Vegetation cover had increased, especially on new lowland area, since a preliminary survey done $10 \mathrm{yr}$ after the eruption, but plant species richness remained poor (only six species). Thus, the plant colonization rate $(0.10$ species/yr) was far slower than that of other volcanic islands such as Krakatau. Most plants (four species) had ocean-dispersed seeds, but two species were likely dispersed via attachment to seabirds. Despite colonization by only a few plant species, there were abundant flower visitors including ants, bugs, a butterfly, and a fly (but no bee species), and the average visitation rate per flower was 5.5 visits $/ 12 \mathrm{hr}$ in total observations. Most of the insects used multiple food sources, concurrently acting as scavengers or herbivores.
\end{abstract}

The process of colonizing remote oceanic islands has attracted many researchers because of the unique opportunity to study the pioneer organisms involved in the process. The central questions that investigators face include how organisms disperse to reach the islands, how species interact in the initial community, and what types of traits are advantageous in colonization of the island environment (Baker 1955, Carlquist 1974, Whittaker 1998).

Recently, molecular phylogenetic data have permitted more accurate speculation about the colonization and speciation history of oceanic islands (Armbruster and Baldwin 1998, Thorpe and Malhotra 1998, Ballard and Sytsma 2000, Emerson 2002, Percy and

\footnotetext{
${ }^{1}$ This study was funded by the Environmental Agency of Japan and the Ministry of Education, Culture, Sports, Science, and Technology. Manuscript accepted 12 September 2005.

${ }^{2}$ Department of Forest Vegetation, Forestry and Forest Products Research Institute, Matsunosato 1, Tsukuba, Ibaraki 305-0903, Japan (e-mail: tetsuabe@ ffpri.affrc.go.jp).
}

Pacific Science (2006), vol. 60, no. 3:355-365 (C) 2006 by University of Hawai'i Press

All rights reserved
Cronk 2002, Price and Clague 2002, Kawakita and Kato 2004, Silvertown 2004). Colonization scenarios derived from limited indirect evidence, however, have been speculative because the invasion process has rarely been observed in real time on young oceanic islands. The most famous studies of colonization processes on a volcanic island have focused on Krakatau Island (Tagawa et al. 1985, Whittaker et al. 1989, 1997, 2000, Thornton 1997), Surtsey Island (Fridriksson 1989, Magnusson and Magnusson 2000, Frederiksen et al. 2001), and Long Island near Papua New Guinea (Edwards and Thornton 2001, Harrison et al. 2001, Thornton et al. 2001). However, each of those new islands lies within several dozen kilometers of the nearest mainland, so their conditions and the resulting challenges to colonizers differ greatly from those of true oceanic islands, which may be located several thousand kilometers from any source of land biota.

Nishino-shima Island $\left(27^{\circ} 14^{\prime} \mathrm{N}, 140^{\circ} 52^{\prime}\right.$ E), which lies $130 \mathrm{~km}$ west of Chichi-jima Island (in the Ogasawara Islands) and about $1,000 \mathrm{~km}$ south of mainland Japan, erupted in 1973. The composition of its biota may be reset by another eruption in the near future. Thus, field observation of the initial 
biota on this young oceanic island provides a precious opportunity to describe the colonization process.

Two preliminary studies have investigated the biota of Nishino-shima Island. Before the 1973 eruption, the flora of the island consisted of three species in 1969 (Asami et al. 1970) (see Table 1). The crew aboard a fishing vessel observed smoke from an eruption in about 1950 (National Institute for Japanese Islands 2004), so it is likely that the vegetation of Nishino-shima Island had already declined as a result of ash deposition from intermittent volcanic activity before 1973 . The flora of this island before the 1969 survey is unknown. In the subsequent visit to the island, Ohsawa and Kurata (1983) reported only four species in the flora $10 \mathrm{yr}$ after the 1973 eruption. In this paper, I report the flora, vegetation, and arthropod fauna that had become established on Nishino-shima Island in 2004 (31 yr after the last eruption).

\section{MATERIALS AND METHODS}

Nishino-shima Island is in the Izu-Mariana Archipelago (Figure 1). Before the eruption of 1973, Nishino-shima Island was believed to have originated after the Quaternary geological period; this is far younger than other islands of the Ogasawara group, which originated in middle Eocene to Oligocene time (Umino 1985). Therefore, several species may have existed on the island before humans first visited, and humans have never historically inhabited the island. In 1973, an eruption occurred just east of the island, and the two islands were then united by tidal erosion and deposition. In this paper, the western plateau ( $25 \mathrm{~m}$ altitude) is referred to as the Old

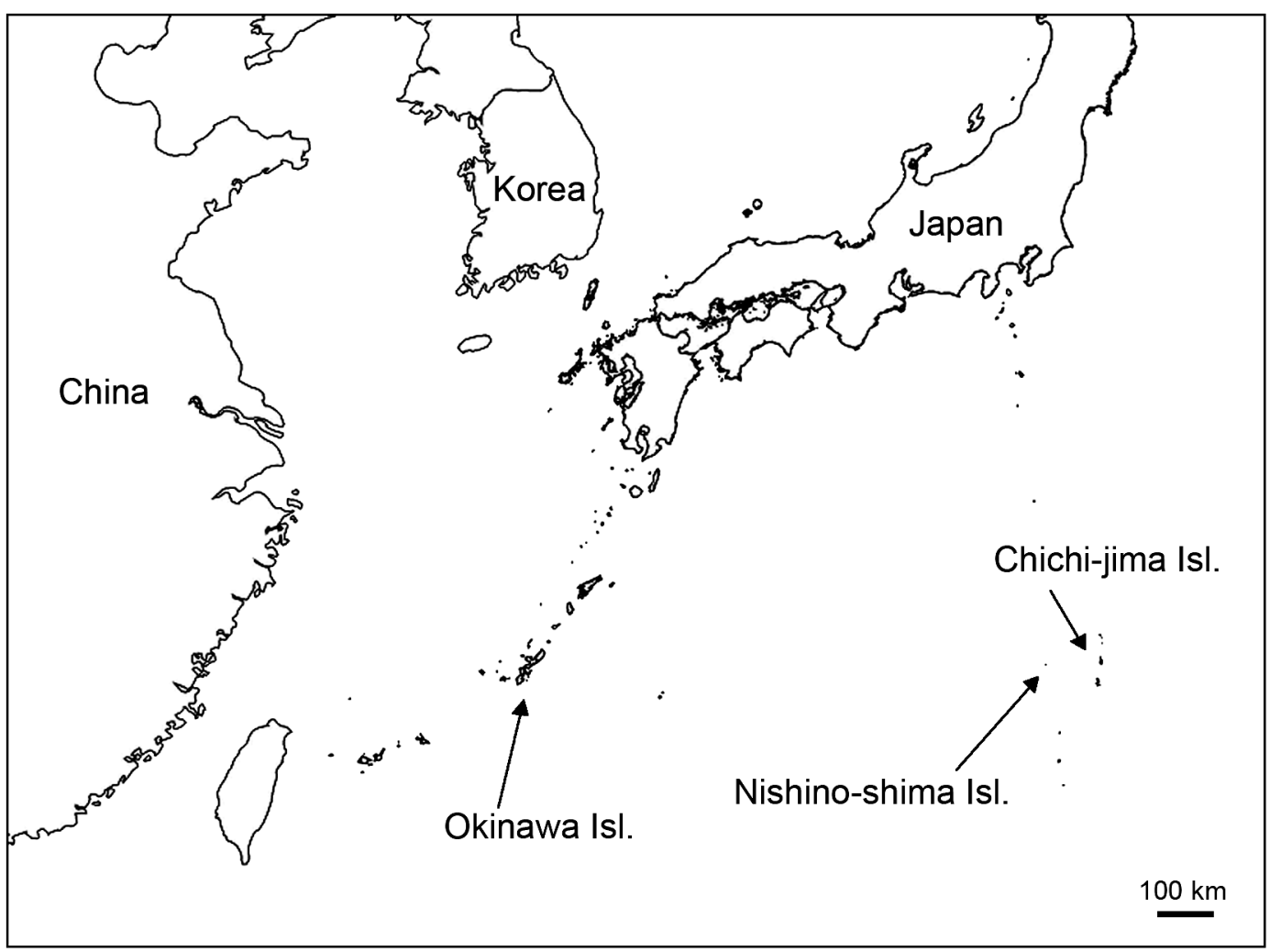

Figure 1. Location of Nishino-shima Island. 
Plateau, and the eastern plateau and middle lowland are referred to as the New Plateau and New Lowland, respectively, reflecting the origins of these parts of the island (see Figure 2).

The Old Plateau consists of andesitic rock and is surrounded by a coastal cliff. Its surface is a dry, immature soil about $30 \mathrm{~cm}$ deep, containing little organic matter and much rock. The New Plateau consists of lava without any soil, and the New Lowland substrate is primarily lava-derived gravel. Salty Nakanoike pond is located in the southeastern part of the island. No data are available concerning climate conditions on Nishino-shima Island, but there is likely to be less precipitation than on Chichi-jima Island (which receives about $1,200 \mathrm{~mm}$ annually) because of its low elevation. Dry conditions have probably combined with the immature soil to slow colonization.

The field survey was conducted in July 2004. I drew a vegetation map and investigated the flora by walking around the island and recording the phytosociological aspects of the established vegetation using 4- $\mathrm{m}^{2}$ quadrats $(n=15)$. Flower visitors were observed on three species of flowering plants (Portulaca oleracea, Vitex rotundifolia, and Ipomoea pes-caprae) for a total of $450 \mathrm{~min}$ by direct observation and by recording visits with a digital video camera. I collected by sweep net any insects that visited the flowers. I also captured other arthropod species gathering on seabird corpses and moving on the soil surface by hand during my traverse of the island. Arthropods were identified to species level by consulting with taxonomic specialists.

\section{RESULTS}

The flora of Nishino-shima Island consisted only of six angiosperms in 2004: $V$. rotundifolia, Eleusine indica, P. oleracea, Echinochloa crusgalli var. caudata, I. pes-caprae, and Tetragonia tetragonoides (Table 1). This represents very poor species diversity compared with that of other volcanic islands (Table 2). Among the 2004 flora, E. indica, P. oleracea, and E. crusgalli var. caudata were recorded on the Old Plateau in 1969 and likely survived the 1973 eruption. In contrast, I. pes-caprae invaded within $5 \mathrm{yr}$ after the eruption (Ohsawa and Kurata 1983), and $V$. rotundifolia and T. tetragonoides invaded between 6 and $31 \mathrm{yr}$ after the eruption. Thus, the migration rate in Nishino-shima Island was 0.10 plant species/ yr during the first $31 \mathrm{yr}$. All species except $T$. tetragonoides exhibited reproductive structures such as flower buds, flowers, or seeds during my survey. Four species exhibit ocean dispersal, and the remaining two species exhibit dispersal via attachment to birds. All plant species had hermaphroditic flowers, and five of the six species were short-lived herbs (Table 1).

Portulaca oleracea dominated the vegetation of Nishino-shima Island (Figure 2, Table 3). The vegetation of the Old Plateau was dominated by $P$. oleracea and E. crus-galli var. caudata and included several widely separated individuals of $E$. indica and T. tetragonoides. Portulaca oleracea also dominated the New Lowland, and $V$. rotundifolia and I. pes-caprae appeared only in the New Lowland. In contrast, the New Plateau consists of a lava substrate that has not yet developed any soil, and it still had no plants 31 years after the eruption (Figure 2). Only the northern area of the New Plateau, where relatively more weathering has progressed than elsewhere, seems likely to support the establishment of vegetation by means of seed recruitment in the near future. In addition, $V$. rotundifolia was spreading along the boundary between the New Plateau and the New Lowland and may eventually extend its distribution upward into the New Plateau. In 2004 there was approximately $50 \%$ vegetation coverage in the Old Plateau, 20\% in the New Lowland, and $0 \%$ in the New Plateau (Figure 2). Two patches of $I$. pes-caprae were found in the New Lowland, but they seemed to have decreased in extent from $20 \mathrm{yr}$ before when $I$. pes-caprae had expanded into a patch approximately $10 \mathrm{~m}$ in diameter (Ono and Okutomi 1985). Each plant community consisted of one to three species and typically covered $20-40 \%$ (range, 5 to $100 \%$ ) of each $4-\mathrm{m}^{2}$ quadrat (Table 2).

In total, I recorded 33 visits to flowers during 450 minutes of observation of three plant 
TABLE 1

Change in the Flora of Nishino-shima Island between 1969 (Asami et al. 1970) and 1983 (Ohsawa and Kurata 1983) and between 1983 and 2004 (This Study)

\begin{tabular}{|c|c|c|c|c|c|c|c|c|}
\hline Species (Family) & 1969 & $1983^{a}$ & 2004 & $\begin{array}{l}\text { Life } \\
\text { Form }\end{array}$ & $\mathrm{Sex}^{b}$ & Dispersal & $\begin{array}{l}\text { Clonal } \\
\text { Growth }\end{array}$ & Distribution \\
\hline $\begin{array}{l}\text { Eleusine indica } \\
\text { (Gramineae) }\end{array}$ & OP & $\mathrm{OP}$ & $\mathrm{OP}, \mathrm{NL}$ & Annual & $\mathrm{H}$ & Epizoochorous & & Worldwide \\
\hline $\begin{array}{l}\text { Portulaca oleracea } \\
\quad \text { (Portulacaceae) }\end{array}$ & $\mathrm{OP}$ & $\mathrm{OP}$ & $\mathrm{OP}, \mathrm{NL}$ & Annual & $\mathrm{H}$ & Ocean & & Worldwide \\
\hline $\begin{array}{l}\text { Echinocbloa crus-galli } \\
\text { var. caudata } \\
\text { (Gramineae) }\end{array}$ & $\mathrm{OP}$ & $\mathrm{OP}$ & $\mathrm{OP}, \mathrm{NL}$ & Annual & $\mathrm{H}$ & Epizoochorous & & Worldwide \\
\hline $\begin{array}{l}\text { Ipomoea pes-caprae } \\
\text { (Convolvulaceae) }\end{array}$ & - & NL (30) & NL & Perennial & $\mathrm{H}$ & Ocean & Yes & Tropical \\
\hline $\begin{array}{l}\text { Vitex rotundifolia } \\
\text { (Verbenaceae) }\end{array}$ & - & - & NL & Shrub & $\mathrm{H}$ & Ocean & Yes & $\begin{array}{c}\text { East Asia and } \\
\text { Oceania }\end{array}$ \\
\hline $\begin{array}{l}\text { Tetragonia } \\
\text { tetragonoides } \\
\text { (Aizoaceae) }\end{array}$ & - & $-(1)$ & $\mathrm{OP}, \mathrm{NL}$ & Perennial & $\mathrm{H}$ & Ocean & Yes & Pacific coast \\
\hline $\begin{array}{l}\text { Calophyllum } \\
\text { inophyllum } \\
\text { (Guttiferae) }\end{array}$ & - & $-(1)$ & - & Tree & $\mathrm{H}$ & Ocean & & $\begin{array}{c}\text { Tropical Asia } \\
\text { and Africa }\end{array}$ \\
\hline $\begin{array}{r}\text { Terminalia catappa } \\
\text { (Combretaceae) }\end{array}$ & - & $-(1)$ & - & Tree & $\mathrm{Gm}$ & Ocean & & $\begin{array}{c}\text { Tropical Asia } \\
\text { and Africa }\end{array}$ \\
\hline $\begin{array}{l}\text { Barringtonia asiatica } \\
\text { (Lecythidaceae) }\end{array}$ & - & $-(2)$ & - & Tree & $\mathrm{H}$ & Ocean & & $\begin{array}{l}\text { East Asia, } \\
\text { Oceania }\end{array}$ \\
\hline Palm sp. & - & $-(2)$ & - & Tree & $?$ & Ocean & & \\
\hline $\begin{array}{c}\text { Entada phaseoloides } \\
\text { (Leguminosae) }\end{array}$ & - & $-(1)$ & - & $\begin{array}{l}\text { Woody } \\
\text { vine }\end{array}$ & $\mathrm{H}$ & Ocean & Yes & $\begin{array}{c}\text { Tropical Asia } \\
\text { and Africa }\end{array}$ \\
\hline
\end{tabular}

Note: OP, Old Plateau; NL, New Lowland.

${ }^{a}$ Number of ocean-dispersed seeds observed by Ohsawa and Kurata (1983) in parentheses.

${ }^{b} \mathrm{H}$, hermaphrodite; Gm, gynomonoecy.

TABLE 2

Floristic Diversity of Some Volcanic Islands after Eruption

\begin{tabular}{|c|c|c|c|c|}
\hline Parameter & Krakatau Island ${ }^{a}$ & Surtsey Island ${ }^{b}$ & Long Island ${ }^{c}$ & Nishino-shima Island \\
\hline Country & Indonesia & Iceland & Papua New Guinea & Japan \\
\hline Latitude & $6.1^{\circ} \mathrm{S}$ & $63.4^{\circ} \mathrm{N}$ & $5.2^{\circ} \mathrm{S}$ & $27.1^{\circ} \mathrm{N}$ \\
\hline Eruption date & 1883 & 1963 & 1645 & 1973 \\
\hline Area $\left(\mathrm{km}^{2}\right)$ & 17 & 2.8 & 330 & 0.2 \\
\hline Altitude (m) & 813 & 150 & 1,280 & 25 \\
\hline $\begin{array}{l}\text { Distance from } \\
\text { nearest mainland }\end{array}$ & $\begin{array}{l}31 \mathrm{~km} \\
\text { (Sumatra Island) }\end{array}$ & $\begin{array}{l}33 \mathrm{~km} \\
\text { (Iceland) }\end{array}$ & $\begin{array}{l}55 \mathrm{~km} \\
\quad \text { (Papua New Guinea) }\end{array}$ & $\begin{array}{r}1,000 \mathrm{~km} \\
\text { (Japan) }\end{array}$ \\
\hline \multirow{3}{*}{$\begin{array}{l}\text { Eruption }(\mathrm{E})+\text { years } \\
\text { (number of } \\
\text { plant species) }\end{array}$} & $E+3(35)$ & $E+5(4)$ & $E+354(305)$ & $E+10(4)$ \\
\hline & $E+25(120)$ & $E+10(13)$ & & $E+31(6)$ \\
\hline & $E+51(290)$ & $E+25(18)$ & & \\
\hline
\end{tabular}

${ }^{a}$ Species richness is of Rakata Island (Whittaker et al. 1992).

${ }^{b}$ Fridriksson (1989).

${ }^{c}$ Harrison et al. (2001). 

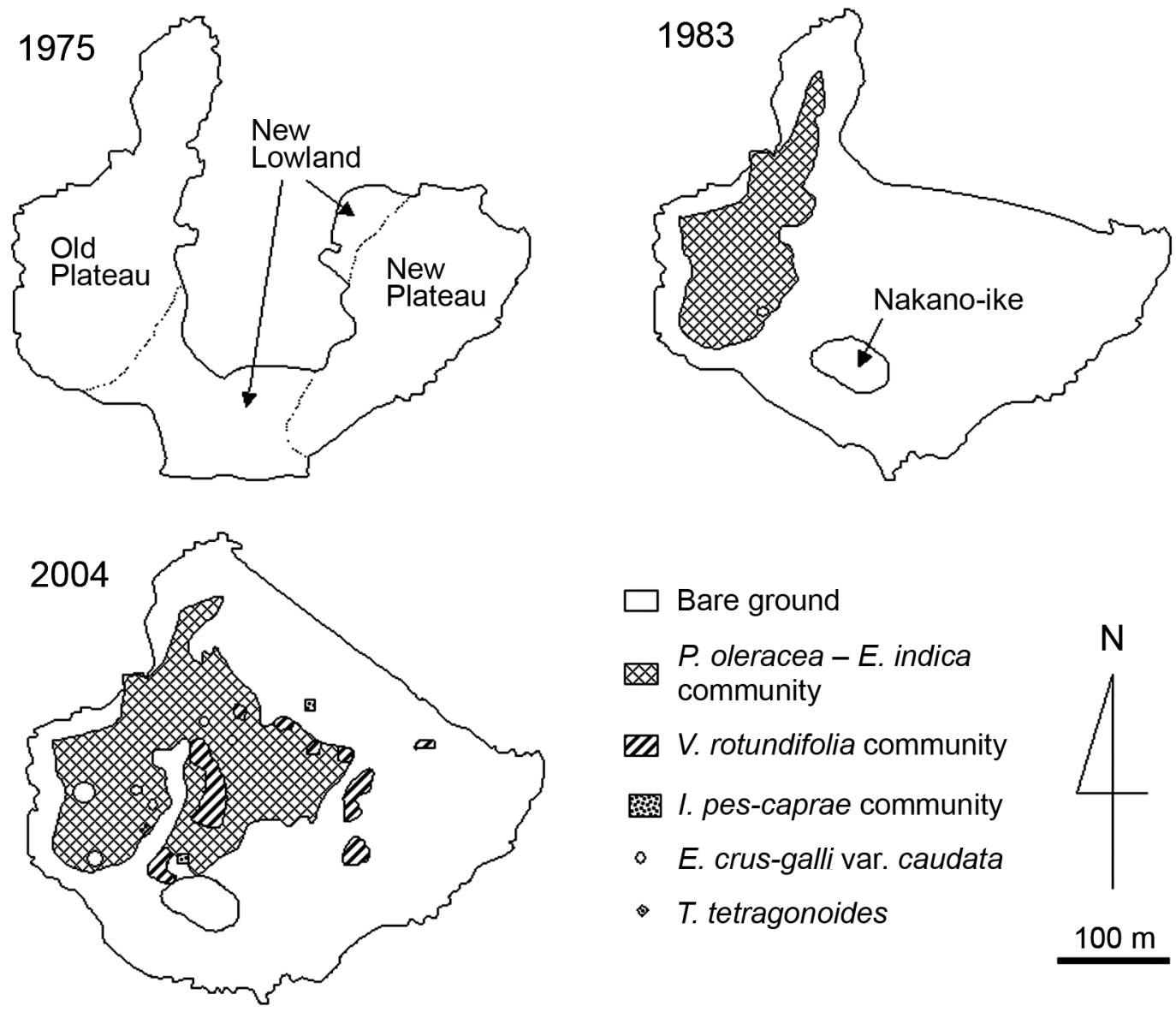

- T. tetragonoides

$100 \mathrm{~m}$

Figure 2. Shape of the three regions of Nishino-shima Island, and vegetation change from shortly after the island's eruption in 1973 until 2004.

species. From this, visitation frequency was calculated as 5.5 visits/flower/12 hr. Although observation time was limited, this frequency is not low compared with that on other islands of the Ogasawara group such as Mukojima, Yome-jima, and Nakoudo-jima (2.4), and Chichi-jima and Haha-jima (5.1) (unpubl. data). Ants accounted for 26 visits $(79 \%$ of the total), followed by bugs (five visits; $15 \%$ [Figure 3]), and one visit each by a butterfly and a fly (Table 4). However, there were no bee species, and the visitation frequency excluding ants was 0.6 visits/flower $/ 12 \mathrm{hr}$, which is lower than on other Ogasawara islands. Thus, although insect visitors were present, their diversity was limited. In addition, I also observed a woolly bear caterpillar (Dermestes ater), earwigs, and spiders among the arthropod fauna (Table 5). All of the identified plant (Table 1) and arthropod (Table 5) species are widely distributed around the world.

\section{DISCUSSION}

Diversity of the flora and fauna of Nishinoshima Island is still very poor compared with that of other volcanic islands, but vegetation is gradually spreading. The plant migration rate was far slower than that observed on 
TABLE 3

Results of Phytosociological Survey of Old Plateau and New Lowland on Nishino-shima Island on 10 July 2004

\begin{tabular}{|c|c|c|c|c|c|c|c|c|c|c|c|c|c|c|c|c|}
\hline \multirow{2}{*}{$\frac{\text { Parameter/Species }^{a}}{\text { Quadrat no. }}$} & \multicolumn{9}{|c|}{ Old Plateau } & \multicolumn{6}{|c|}{ New Lowland } & \multirow[t]{2}{*}{ Freq } \\
\hline & 4 & 5 & 6 & 7 & 8 & 9 & 10 & 11 & 12 & 1 & 3 & 13 & 15 & 2 & 14 & \\
\hline Elevation (m) & 10 & 10 & 10 & 15 & 15 & 25 & 20 & 20 & 15 & 5 & 5 & 5 & 5 & 5 & 5 & \\
\hline Slope $\left(^{\circ}\right)$ & 5 & 0 & 0 & 0 & 0 & 0 & 0 & 0 & 3 & 0 & 0 & 0 & 0 & 0 & 0 & \\
\hline Exposure & $\mathrm{S} 60^{\circ} \mathrm{E}$ & - & - & - & - & - & - & - & $\mathrm{N} 30^{\circ} \mathrm{W}$ & - & - & - & - & - & - & \\
\hline Area $\left(\mathrm{m}^{2}\right)$ & 4 & 4 & 4 & 4 & 4 & 4 & 4 & 4 & 4 & 4 & 4 & 4 & 4 & 4 & 4 & \\
\hline Height $(\mathrm{cm})$ & 5 & 30 & 25 & 25 & 5 & 20 & 5 & 5 & 50 & 20 & 20 & 30 & 20 & 30 & 30 & \\
\hline Cover (\%) & 40 & 50 & 20 & 30 & 20 & 5 & 100 & 100 & 80 & 30 & 30 & 40 & 40 & 40 & 80 & \\
\hline No. of species & 1 & 2 & 3 & 3 & 1 & 3 & 1 & 1 & 1 & 2 & 2 & 2 & 1 & 2 & 1 & \\
\hline Portulaca oleracea & 3 & 1 & 1 & 1 & 2 & + & 5 & 5 & & 3 & 2 & 2 & 3 & 2 & & 13 \\
\hline Eleusine indica & & 3 & 2 & 2 & & 1 & & & 5 & 1 & 2 & 3 & & & & 8 \\
\hline $\begin{array}{l}\text { Echinochloa crus-galli } \\
\quad \text { var. caudata }\end{array}$ & & & & 1 & & & & & & & & & & & & 1 \\
\hline $\begin{array}{l}\text { Tetragonia } \\
\text { tetragonoides }\end{array}$ & & & & & & + & & & & & & & & & & 1 \\
\hline Iротоеа реs-сарrae & & & & & & & & & & & & & & & 5 & 1 \\
\hline Vitex rotundifolia & & & & & & & & & & & & & & 3 & & 1 \\
\hline Community no. ${ }^{b}$ & 1 & 1 & 1 & 1 & 1 & 1 & 1 & 1 & 1 & 1 & 1 & 1 & 1 & 2 & 3 & \\
\hline
\end{tabular}

${ }^{a}$ Numbers for species refer to cover estimates as follows:,$+<1 \% ; 1,1-10 \% ; 2,10-25 \% ; 3,25-50 \% ; 4,50-75 \% ; 5,75-100 \%$.

${ }^{b} 1$, O. oleracea-E. indica community; $2, V$. rotundifolia community; $3, I$. pes-caprae community.

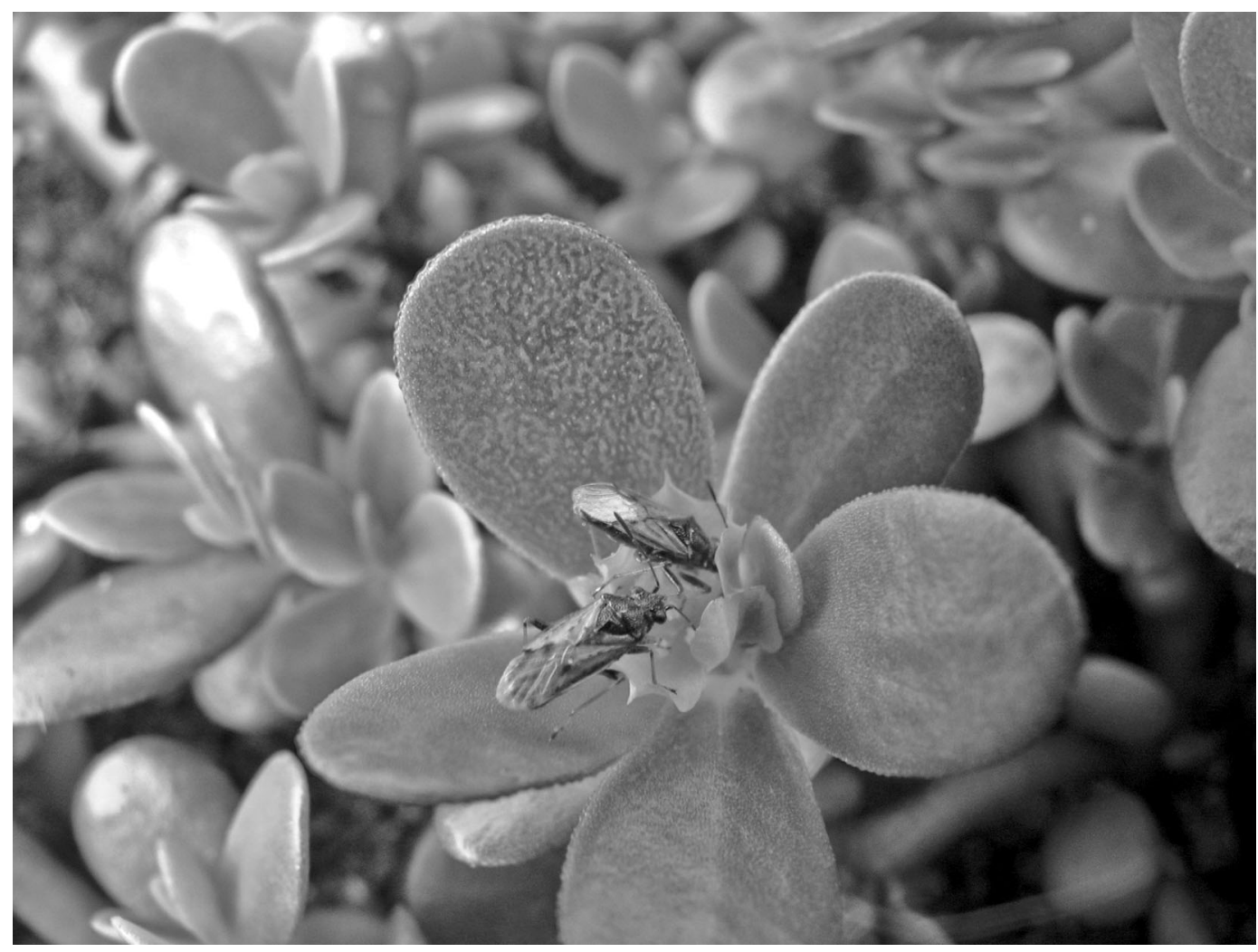

Figure 3. Two bugs (Nysius sp.) visiting a Portulaca oleracea flower. 
Krakatau Island at the first colonization phase (2.78 species/yr [Whittaker 1998]). Of the flora observed in 2004, $V$. rotundifolia, T. tetragonoides, I. pes-caprae, and several species in the genus Portulaca are common along coastlines of Pacific islands (Whistler 1992), so they likely arrived by ocean dispersal. A high proportion of ocean-dispersed species has also been reported for the early phases of succession in the flora on other newly emerged islands (Thornton 1996, 1997). Although Ohsawa and Kurata (1983) recorded several ocean-dispersed seeds (I. pes-caprae, T. tetragonoides, Terminalia catappa, Calophyllum inophyllum, Barringtonia asiatica, Entada sp., and coconuts) along the coast of Nishinoshima Island, only two of these species (I. pescaprae and $T$. tetragonoides) established successfully after the 1973 eruption. Thus, plant colonization of some new islands seems to

TABLE 4

Flower Visitors and Number of Visits on Nishino-shima Island

\begin{tabular}{lrlccrr}
\hline \hline & & \multicolumn{4}{c}{ Visitors } \\
\cline { 5 - 6 } Flowers & Time & $(\mathrm{min})$ & Fly & Butterfly & Bugs & Ants \\
\hline Portulaca oleracea & 90 & & & 5 & 1 \\
Vitex rotundifolia & 280 & 1 & 1 & & 16 \\
Ipomoea pes-caprae & 80 & & & & 9 \\
\hline
\end{tabular}

be difficult even after propagules arrive at the island.

All the plant species on Nishino-shima Island, including E. indica and E. crus-galli var. caudata, whose seeds are dispersed by attachment to birds (epizoochory), are cosmopolitan, with a worldwide or wide distribution, and there are no species endemic to the Ogasawara Islands, Japan, or Taiwan. The presence of cosmopolitan arthropod fauna agreed with the pattern of occurrence of fauna on other volcanic islands (New and Thornton 1988, Thornton et al. 1988, Edwards and Thornton 2001). Birds observed on the island were eight colonizers (Sula leucogaster, S. dactylatra, Anous stolidus, Sterna fuscata, Thalasseus bergii, Bulweria bulwerii, Puffinus pacificus, and Oceanodroma tristrami) and three noncolonizers (Egretta garzetta, Pluvialis fulva, and Arenaria interpres) (Kawakami et al. 2005). In particular, S. leucogaster nested at high density in vegetated patches on the Old Plateau and New Lowland (Figure 4). Nests of these seabirds may represent an important disturbance factor in terms of plant recruitment, and the deposition of guano by the birds is likely to accelerate the development of soils suitable for vegetation development.

On Rakata Island (in the Krakatau Islands), 120 plant species were present only $25 \mathrm{yr}$ after the 1883 eruption (Whittaker et al. 1992) (Table 2). Because Rakata Island is at least 85

TABLE 5

Arthropod Fauna Observed on Nishino-shima Island

\begin{tabular}{lccllll}
\hline \hline Species & $1983^{a}$ & $2004^{b}$ & \multicolumn{1}{c}{ Food Items } & Dispersal & Distribution \\
\hline Spider & - & OP, NL & Anthropod & Air & \\
Ant (Tetramorium bicarinatum) & - & OP, NL & Nectar, pollen, corpse & Debris rafting & Tropical \\
Ant (Pheidole nodus var. praevexata $)$ & Yes & - & Nectar, pollen, corpse & Debris rafting & Asia \\
Butterfly (Vanessa indica) & - & OP, NL & Nectar & Flight & Worldwide \\
Woolly bear (Dermestes ater) & Yes & NL & Corpse & Debris rafting & Worldwide \\
Earwig (Anisolabididae) & - & NL & Corpse & Debris rafting & \\
Bug (Nysius sp.) & - & OP, NL & Nectar, plant body & Debris rafting & \\
Moth (Spoladea recurvalis) & - & NL & Nectar & Flight & Worldwide \\
Fly (Muscidae) & - & OP, NL & Nectar, pollen, corpse & Debris rafting & \\
Dragonfly (Pantala flavescens) & Yes & - & Arthropod & Flight & Worldwide \\
\hline
\end{tabular}

${ }^{a}$ Records for 1983 from Ohsawa and Kurata (1983).

${ }^{b}$ OP, Old Plateau; NL, New Lowland. 


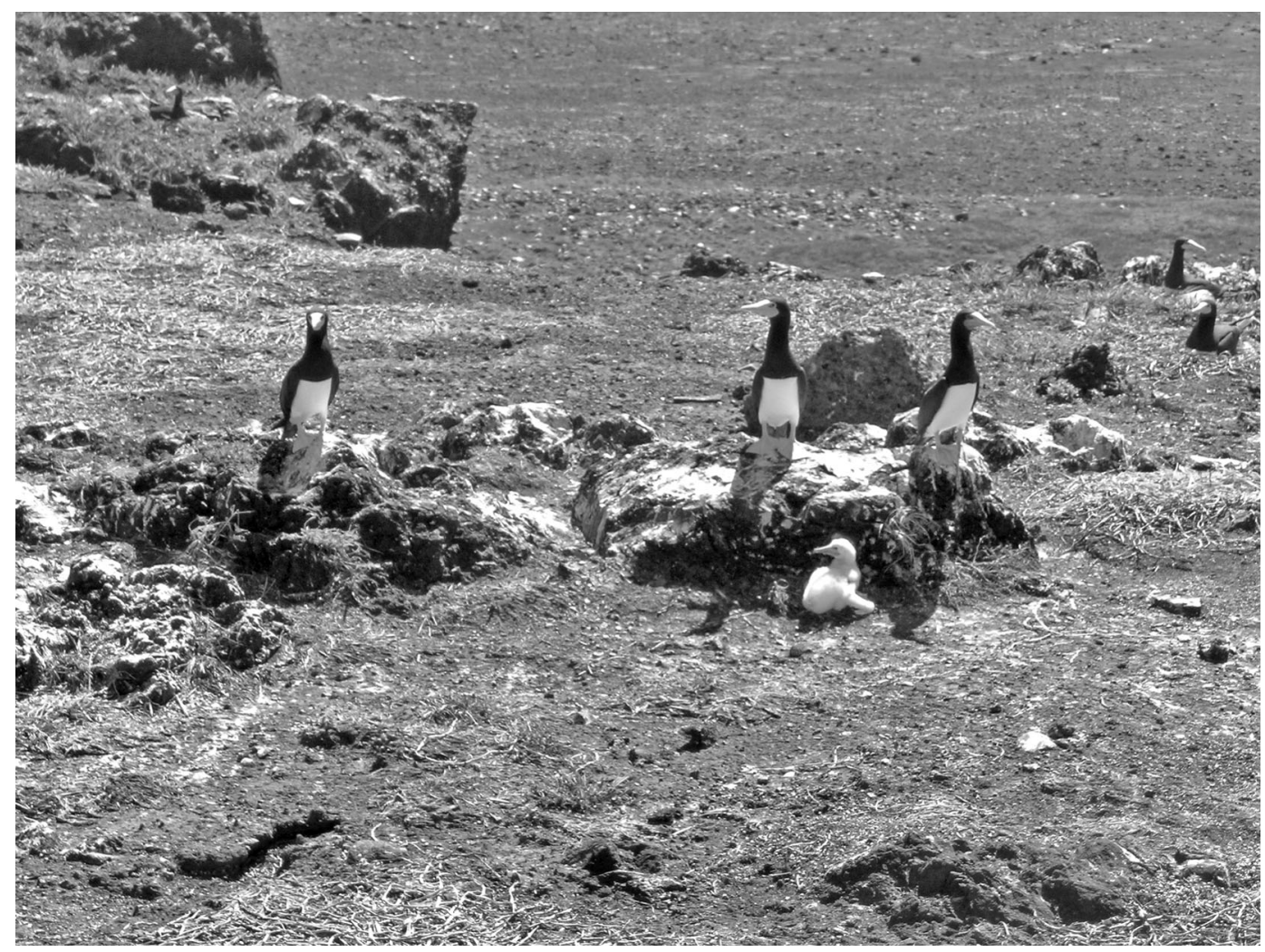

Figure 4. Nesting seabirds (Sula leucogaster).

times the size of Nishino-shima and is close (within $40 \mathrm{~km}$ ) to large neighboring islands (Java and Sumatra), the low barrier to dispersal makes the colonization process faster than on oceanic islands located farther from other sources of biota. The floral richness on Rakata in 1989 had reached 410 species (Thornton 1996), a level that is already larger than the diversity of native plants in the Ogasawara Islands (327 species). This means that the time scale for colonization of remote oceanic islands is considerably longer than has been indicated by previous studies of volcanic islands nearer to other land.

On Krakatau Island, six endozoochorous plant species had already been recorded only $13 \mathrm{yr}$ after the eruption (Thornton 1997), and 124 bird- or bat-dispersed plant species had migrated to the island within $109 \mathrm{yr}$ (Whittaker and Jones 1994). However, there were no endozoochorous plant species on Nishino-shima 31 yr after the 1973 eruption. Frugivorous land birds may not settle on a new island until after the vegetation has developed and produced a food source for the birds. In contrast, ocean dispersal for longdistance dispersal has occurred with higher frequency than previously considered (Higgins et al. 2003, de Queiroz 2005). Several patches of $V$. rotundifolia became established after 1983 in the New Lowland areas of Nishino-shima. Because the distance among patches was more than $100 \mathrm{~m}$, multiple colonizations probably occurred successfully during the last 20 yr. Endozoochory is unlikely to offer an advantage in terms of immigration to a remote island early on compared with ocean dispersal. Although the island flora is dominated by species dispersed by means of seeds in fleshy fruit (Ono and Sugawara 
1981, Lloyd 1985, Webb and Kelly 1993), the dominance of endozoochory in island flora is likely to result from other reasons, such as a larger species pool in the flora of nearby land, rather than solely from a higher migration rate per species (Porter 1984).

In spite of the poor diversity of the island's flora, flies, butterflies, bugs, and ants visited the flowers on Nishino-shima Island. Among the visitors, the butterfly Vanessa indica was observed only once, so this insect probably arrived by chance from somewhere distant. Other flower visitors had multiple sources of food, concurrently acting as scavengers or herbivores. Some studies have reported that a wide range of arthropod taxa can invade the unvegetated habitat that exists after an eruption, and predators and scavengers usually dominate this community (Ball and Glucksman 1975, Howarth 1979, New and Thornton 1988, Thornton et al. 1988, Edwards and Thornton 2001). Such types of insects also act as pollinators of pioneer plants during the early stages of plant colonization. I found no bee species on Nishino-shima Island. Insects that depend only on flowers for their food may have difficulty surviving due to the limited floral availability and diversity. The colonization of flower visitors was also slower than on Krakatau, where bees from genera such as Apis and Xylocora visited flowers as early as $37 \mathrm{yr}$ after the eruption (Thornton 1997).

The Nishino-shima flora is still in its initial stages of colonization even $31 \mathrm{yr}$ after the 1973 eruption. Thus, continuing study of Nishino-shima as colonization progresses will provide new insights into island colonization theory.

\section{ACKNOWLEDGMENTS}

I thank Takaya Yasui, Yasurou Isobe, Kazuto Kawakami, and the National Forest Division of Ogasawara General Office for field assistance. Keiko Hamaguchi, Masahiro Isono, Yukinobu Nakatani, Koji Yasuda, Teruo Katsuyama, and Shun'ichi Makino assisted with species identification. I am also grateful to the anonymous referees for their useful comments on the manuscript.

\section{Literature Cited}

Armbruster, W. S., and B. G. Baldwin. 1998. Switch from specialized to generalized pollination. Nature (Lond.) 394:632.

Asami, S., T. Tsuyama, and Y. Hasuo. 1970. The Volcano Islands and Nishino-shima Island. Pages 211-224 in T. Tsuyama and S. Asami, eds. Nature in the Bonin Islands. Hirokawa Publishing Co., Tokyo [in Japanese].

Baker, H. G. 1955. Self-compatibility and establishment after "long-distance" dispersal. Evolution 9:347-349.

Ball, E. E., and J. Glucksman. 1975. Biological colonization of Motmot, a recently created tropical island. Proc. R. Soc. Lond. B Biol. Sci. 190:421-442.

Ballard, H. E., Jr., and K. J. Sytsma. 2000. Evolution and biogeography of the woody Hawaiian violets (Viola, Violaceae): Arctic origins, herbaceous ancestry and bird dispersal. Evolution 54:1521-1532.

Carlquist, S. 1974. Island biology. Columbia University Press, New York.

de Queiroz, A. 2005. The resurrection of oceanic dispersal in historical biogeography. Trends Ecol. Evol. 20:68-73.

Edwards, J. S., and I. W. B. Thornton. 2001. Colonization of an island volcano, Long Island, Papua New Guinea, and an emergent island, Motmot, in its caldera lake. VI. The pioneer arthropod community of Motmot. J. Biogeogr. 28:13791388.

Emerson, B. C. 2002. Evolution on oceanic islands: Molecular phylogenetic approaches to understanding pattern and process. Mol. Ecol. 11:951-966.

Frederiksen, H. B., H.-O. Kraglund, and F. Ekelund. 2001. Macrofaunal primary succession on the volcanic island of Surtsey, Iceland. Polar Res. 20:61-73.

Fridriksson, S. 1989. The volcanic island of Surtsey, Iceland, a quarter-century after it 'rose from the sea.' Environ. Conserv. 16:157-162.

Harrison, R. D., R. Yamuna, and I. W. B. Thornton. 2001. Colonization of an island volcano, Long Island, Papua New Guinea, and an emergent island, Motmot, in its cal- 
dera lake. II. The vascular flora. J. Biogeogr. 28:1311-1337.

Higgins, S. I., R. Nathan, and M. L. Cain. 2003. Are long-distance dispersal events in plants usually caused by nonstandard means of dispersal? Ecology 84:19451956.

Howarth, F. G. 1979. Neogeoaeolian habitats on new lava flows on Hawaii Island: An ecosystem supported by windborne debris. Pac. Insects 20:133-144.

Kawakami, K., Y. Yamamoto, and K. Horikoshi. 2005. The seabird fauna of Nishinoshima Island, the Bonin Islands, southern Japan. Strix 23:159-166 [in Japanese].

Kawakita, A., and M. Kato. 2004. Evolution of obligate pollination mutualism in New Caledonian Phyllanthus (Euphorbiaceae). Am. J. Bot. 91:410-415.

Lloyd, D. G. 1985. Progress in understanding the natural history of New Zealand plants. N. Z. J. Bot. 23:707-722.

Magnusson, B., and S. H. Magnusson. 2000. Vegetation on Surtsey, Iceland, during 1990-1998 under the influence of breeding gulls. Surtsey Res. 11:9-20.

National Institute for Japanese Islands. 2004. Shimadas. Sanshu-sha Ltd., Tokyo [in Japanese].

New, T. R., and I. W. B. Thornton. 1988. A pre-vegetation population of crickets subsisting on allochthonous aeolian debris on Anak Krakatau. Philos. Trans. R. Soc. Lond. B Biol. Sci. 322:481-485.

Ohsawa, M., and Y. Kurata. 1983. Invasion of plants in a new volcanic island, Nishinoshima-sinto, Bonin Islands. Saishu-toShiiku 45:377-380 [in Japanese].

Ono, M., and K. Okutomi. 1985. Endemic species and vegetation of the Bonin Islands. Aboc-sha Co., Ltd. Publishers, Kamakura [in Japanese].

Ono, M., and T. Sugawara. 1981. An analysis of the flowering plant flora of the Ogasawara (Bonin) Islands with regard to their mode of dispersal. Ogasawara Res. 5:2540.

Percy, D. M., and Q. C. B. Cronk. 2002. Different fates of island brooms: Contrasting evolution in Adenocarpus, Genista, and Te- line (Genisteae, Fabaceae) in the Canary Islands and Madeira. Am. J. Bot. 89:854864.

Porter, D. M. 1984. Relationships of the Galapagos flora. Biol. J. Linn. Soc. 21:243251.

Price, J. P., and D. A. Clague. 2002. How old is the Hawaiian biota? Geology and phylogeny suggest recent divergence. Proc. R. Soc. Lond. B Biol. Sci. 269:2429-2435.

Silvertown, J. 2004. The ghost of competition past in the phylogeny of island endemic plants. J. Ecol. 92:168-173.

Tagawa, H., E. Suzuki, T. Partomihardjo, and A. Suriadarma. 1985. Vegetation and succession on the Krakatau Islands, Indonesia. Vegetatio 60:131-145.

Thornton, I. 1996. The origins and development of island biotas as illustrated by Krakatau. Pages 67-90 in A. Keast and S. E. Miller, eds. The origin and evolution of Pacific island biotas, New Guinea to eastern Polynesia: Patterns and processes. SPB Academic Publishing, Amsterdam.

. 1997. Krakatau: The destruction and reassembly of an island ecosystem. Harvard University Press, Cambridge, Massachusetts.

Thornton, I. W. B., T. R. New, D. A. McLaren, H. K. Sudarman, and P. J. Vaughan. 1988. Air-borne arthropod fall-out on Anak Krakatau and a possible prevegetation pioneer community. Philos. Trans. R. Soc. Lond. B Biol. Sci. 322:471479.

Thornton, I. W. B., S. Cook, J. S. Edwards, R. D. Harrison, C. Schipper, M. Shanahan, R. Singadan, and R. Yamuna. 2001. Colonization of an island volcano, Long Island, Papua New Guinea, and an emergent island, Motmot, in its caldera lake. VII. Overview and discussion. J. Biogeogr. 28:1389-1408.

Thorpe, R. S., and A. Malhotra. 1998. Molecular and morphological evolution within small islands. Pages 67-82 in P. R. Grant, ed. Evolution on islands. Oxford University Press, Oxford, United Kingdom.

Umino, S. 1985. Volcanic geology of Chichijima, the Bonin Islands (Ogasawara Islands). J. Geol. Soc. Jpn. 91:505-523. 
Webb, C. J., and D. Kelly. 1993. The reproductive biology of the New Zealand flora. Trends Ecol. Evol. 8:442-447.

Whistler, W. A. 1992. Flowers of the Pacific island seashore: A guide to the littoral plants of Hawaici, Tahiti, Samoa, Tonga, Cook Islands, Fiji and Micronesia. University of Hawai'i Press, Honolulu.

Whittaker, R. J. 1998. Island biogeography: Ecology, evolution, and conservation. Oxford University Press, Oxford, United Kingdom.

Whittaker, R. J., and S. H. Jones. 1994. The role of frugivorous bats and birds in the rebuilding of a tropical forest ecosystem, Krakatau, Indonesia. J. Biogeogr. 21:245258.

Whittaker, R. J., M. B. Bush, and K. Rich- ards. 1989. Plant recolonization and vegetation succession on the Krakatau Islands, Indonesia. Ecol. Monogr. 59:59-123.

Whittaker, R. J., M. B. Bush, T. Partomihardjo, N. M. Asquith, and K. Richards. 1992. Ecological aspects of plant colonization of the Krakatau Islands. GeoJournal 28:201-211.

Whittaker, R. J., S. H. Jones, and T. Partomihardjo. 1997. The rebuilding of an isolated rain forest assemblage: How disharmonic is the flora of Krakatau? Biodivers. Conserv. 6:1671-1696.

Whittaker, R. J., R. Field, and T. Partomihardjo. 2000. How to go extinct: Lessons from the lost plants of Krakatau. J. Biogeogr. 27:1049-1064. 
